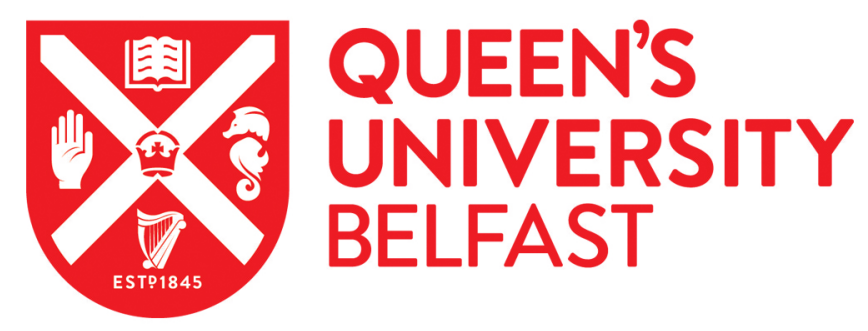

\title{
Increased susceptibility to delayed genetic effects of low dose X- irradiation in DNA repair deficient cells
}

Kashino, G., Suzuki, K., Kodama, S., Watanabe, M., \& Prise, K. M. (2013). Increased susceptibility to delayed genetic effects of low dose X-irradiation in DNA repair deficient cells. International journal of radiation biology, 89(4), 295-300. https://doi.org/10.3109/09553002.2013.752596

\section{Published in:}

International journal of radiation biology

\section{Document Version:}

Peer reviewed version

\section{Queen's University Belfast - Research Portal:}

Link to publication record in Queen's University Belfast Research Portal

\section{Publisher rights}

This is an Accepted Manuscript of an article published by Taylor \& Francis in International Journal of Radiation Biology on 17 December 2012, available online: http://www.tandfonline.com/doi/full/10.3109/09553002.2013.752596

\section{General rights}

Copyright for the publications made accessible via the Queen's University Belfast Research Portal is retained by the author(s) and / or other copyright owners and it is a condition of accessing these publications that users recognise and abide by the legal requirements associated with these rights.

Take down policy

The Research Portal is Queen's institutional repository that provides access to Queen's research output. Every effort has been made to ensure that content in the Research Portal does not infringe any person's rights, or applicable UK laws. If you discover content in the Research Portal that you believe breaches copyright or violates any law, please contact openaccess@qub.ac.uk. 
Title

Increased susceptibility to delayed genetic effects of low dose X-irradiation in DNA repair deficient cells

Authors

Genro Kashino $^{1 *}$, Keiji Suzuki ${ }^{2}$, Seiji Kodama ${ }^{3}$, Masami Watanabe ${ }^{4}$, Kevin M. Prise $^{5}$

Affiliation

1. Advanced Molecular Imaging Center, School of Medicine, Oita University, 1-1 Idaigaoka,

Hasama, Yufu city, Oita 879-5593, Japan

2. Course of Life Sciences and Radiation Research, Graduate School of Biomedical Sciences,

Nagasaki University, 1-12-4 Sakamoto, Nagasaki 852-8523, Japan

3. Laboratory of Radiation Biology, Division of Radiation Life Science, Research Reactor

Institute, Kyoto University, 2-1010 Asashiro-nishi, Kumatori-cho, Sennan-gun, Osaka 590-0458,

Japan

4. Radiation Biology Laboratory, Radiation Research Center, Frontier Science Innovation

Center, Organization for University-Industry-Government Cooperation, Osaka Prefecture

University, 1-2 Gakuen-cho, Sakai, Osaka 599-8570, Japan 
5. Centre for Cancer Research and Cell Biology, Queen's University Belfast, 97 Lisburn Road, Belfast, BT9 7BL, UK

Author for correspondence

* Dr Genro Kashino

Advanced Molecular Imaging Center, School of Medicine, Oita University, 1-1 Idaigaoka,

Hasama, Yufu city, Oita 879-5593, Japan

Tel; +81-97-586-6318,

Fax; +81-97-586-6314

E-mail; kashino@oita-u.ac.jp

Key words

genomic instability, bystander effect, DNA repair, low-dose irradiation

Running title

Genomic instability in repair deficient cells

\section{Abstract}

Purpose: To examine whether the levels of micronuclei induction, as a marker for genomic 
instability in the progeny of X-irradiated cells, correlates with DNA repair function.

Materials and methods : Two repair deficient cell lines (X-ray repair cross-complementing 1 (XRCC1) deficient cell line (EM9) and X-ray repair cross complementing 5 (XRCC5; Ku80)

deficient X-ray sensitive Chinese hamster ovary (CHO) cell line (xrs5)) were used in addition to wild-type $\mathrm{CHO}$ cells. These cells were irradiated with low doses of X-rays (up to $1 \mathrm{~Gy}$ ). Seven days after irradiation, micronuclei formed in binucleated cells were counted. To assess the contribution of the bystander effect micronuclei induction was measured in progeny of non-irradiated cells co-cultured with cells that had been irradiated with $1 \mathrm{~Gy}$.

Results : The delayedinduction of micronuclei in 1 Gy-irradiated cells was observed in normal CHO and EM9 but not in xrs5. In the clone analysis, progenies of xrs5 under bystander conditions showed significantly higher levels of micronuclei, while CHO and EM9 did not. Conclusion: Genomic instability induced by X-irradiation is associated with DSB (double strand break) repair, even at low doses. It is also suggested that bystander signals, which lead to genomic instability, may be enhanced when DSB repair is compromised.

\section{Introduction}

Radiation induced genomic instability has been reported by many groups (Kadhim et al. 1992; Little et al. 1997; Morgan. 2003ab; Suzuki et al. 2003, 2009, 2010; Somodi et al. 
2005; Seoane et al. 2007; Toyokuni et al. 2009). This form of damage is apparent in growing cells several generations after irradiation of the initial cell population. Such damage can be indicated by abnormal phenotypes, including reproductive cell death, delayed chromosome aberration, gene mutation and transformation. It has been suggested that genomic instability is one of the driving forces in radiation induced carcinogenesis. Some evidence suggests that radiation induced genomic instability has been caused by DNA double strand breaks (DSB) (Chang and Little. 1992; Suzuki et al. 2003, 2010). Therefore, understanding the DNA repair mechanisms involved in the expression of genomic instability is important.

There has been significant study of the "radiation-induced bystander effect" as an example of a non-targeted effect of ionizing radiation exposure. This effect is thought to be important for risk estimation of radiation carcinogenesis as it predominantly occurs at low doses (Sawant et al. 2001). Not only DNA damage but also epigenetic change is also observed in the bystander effect (Koturbash et al. 2007; Ilnytskyy and Kovalchuk 2011). Although there are increasing numbers of studies of the bystander response (Hamada et al. 2011; Chai and Hei 2008; Prise and O’Sullivan 2009), the mechanisms are not fully understood. It is important to determine the interrelationship between bystander effects and genomic instability.

For DSB, two main mechanisms have been characterized; homologous recombination (HR) and non-homologous end joining (NHEJ). Of these, NHEJ is the major player in the repair 
of radiation-induced DNA double strand breaks in mammalian cells (Valerie and Povirk 2003;

Goodarzi et al. 2010). In this repair process the Ku70/80 (X-ray cross complementing 6/5

(XRCC 6/5)) protein complex stabilizes the ends of digested DNA strands, DNA-Protein Kinase catalytic subunits (DNA-PKcs) become activated on association with the Ku complex, which in turn may activate the enzyme ligase IV with XRCC4 (X-ray cross complementing 4), Finally, activated ligase IV leads to rejoining reactions in the two ends of DNA (Mahaney et al. 2009). From cellular studies, it is well known that a defect of each protein in this process leads to higher cell killing after irradiation because of less repair ability of DNA double strand breaks (Nussenzweig et al. 1996). Base damage on DNA caused by irradiation is also well characterized. This damage is repaired by a base excision repair process. XRCC1 is important for activation of ligase III which links the digested strands in this repair process (Caldecott et al. 1994; Sterpone and Cozzi 2010). A defect in XRCC1 leads to hypersensitivity to alkylating agents (Shen et al. 1998).

In these investigations, repair deficient cell lines derived from Chinese hamster ovary (CHO) cells have been used as described in previous reports (Thacker and Zdzienicka 2003; Kashino et al. 2004; Somodi et al. 2005). In the present study, we investigated the X-ray induced delayed effects in repair deficient $\mathrm{CHO}$ cell lines to elucidate the mechanisms of genomic instability induced by lower doses of X-irradiation. 


\section{Materials and Methods}

Cell culture

Wild type CHO cells and the Ku80 deficient X-ray sensitive CHO cell line, xrs5, were kindly supplied by Dr Tom K. Hei (Columbia University). EM9 cells, which are an X-ray repair cross-complementing 1 (XRCC1) deficient cell line, were purchased from ATCC (American Type Culture Collection, Manassas, USA). Cells were cultured in Minimum Essential Medium (MEM) alpha medium (Invitrogen Corporation, Paisley, UK) supplemented with $10 \%$ fetal bovine serum (FBS, Helena Biosciences Europe, Gateshead, UK), 100 units $/ \mathrm{ml}$ penicillin and $100 \mu \mathrm{g} / \mathrm{ml}$ streptomycin (Invitrogen). Cells were maintained at $37^{\circ} \mathrm{C}$ in a humidified atmosphere with $5 \% \mathrm{CO}_{2}$.

\section{$X$-irradiation}

Exponentially growing cells in $25 \mathrm{~cm}^{2}$ flasks (T25, BD, Franklin Lakes, USA) were irradiated at doses of $0.2,0.5$ or 1 Gy using an X-ray generator (Pantak IV at Gray Cancer Institute, Northwood, UK) operating at $240 \mathrm{kVp}$ and $13 \mathrm{~mA}$ with a filter system, composed of a $0.25 \mathrm{~mm} \mathrm{Cu}$ plus $1 \mathrm{~mm} \mathrm{Al}$ filter and a $4.3 \mathrm{~mm} \mathrm{Al} \mathrm{flatting} \mathrm{filter,} \mathrm{at} \mathrm{a} \mathrm{dose} \mathrm{rate} \mathrm{of} 0.5 \mathrm{~Gy} / \mathrm{min}$, or using an X-ray generator (Softex, Tokyo, Japan) at $150 \mathrm{kVp}$ and $5 \mathrm{~mA}$ with a $0.1 \mathrm{~mm} \mathrm{Cu}$ filter, at a dose rate of $0.49 \mathrm{~Gy} / \mathrm{min}$. 
Micronucleus assay

The micronucleus assay used was as described previously (Kashino et al. 2004, 2007).

Cells were irradiated with $0.2,0.5$, and 1 Gy of X-rays as described above. To investigate acute effects cells were treated with $2 \mu \mathrm{g} / \mathrm{ml}$ cytochalasin B (Wako, Osaka, Japan) for $24 \mathrm{~h}$ immediately after X-irradiation. To investigate delayed effects cells were cultured for 7 days after irradiation before treatment with cytochalasin B. Cells were then harvested and treated with $3 \mathrm{ml}$ of hypotonic $(0.1 \mathrm{M}) \mathrm{KCl}$ (Wako) for $20 \mathrm{~min}$, and then fixed with $3 \mathrm{ml}$ of methanol (Wako) - acetic acid (Wako) (5:1 v/v). The cell suspensions were centrifuged at $145 \mathrm{~g}$ for $5 \mathrm{~min}$, the supernatant was discarded and cells were re-suspended in $4 \mathrm{ml}$ methanol-acetic acid solution and incubated on ice for $5 \mathrm{~min}$. Following re-centrifugation, the supernatant was discarded and 0.5-1 ml methanol-acetic acid solution was added. Cells were suspended and dropped onto glass slides (Matsunami Glass, Okasa, Japan). The slides were stained with 7.5\% Giemsa (Merck chemical, Tokyo, Japan) for 40 min. Percentage of binucleated cells with micronuclei were counted microscopically as described previously (Fench et al. 2003). The yields of micronuclei per 6000 binucleated cells in three independent experiments were scored in each group.

Clonal analysis of delayed effect by co-culture method

Clonal analyses for delayed effects in directly irradiated and bystander conditions were performed using a co-culture method in CHO, EM-9 and xrs5 cells. To distinguish the 
irradiated cells and non-irradiated cells in co-culture, we used hypoxanthine phosphoribosyltransferase (HPRT) mutant and normal cells (HPRT is wild-type). HPRT mutant cells were obtained spontaneously after $60 \mu \mathrm{M}$ 6-thioguanine (6TG, Tokyo Kasei, Tokyo, Japan) selection. In co-culture of irradiated cells with non-irradiated cells, $5 \times 10^{5}$ of $H P R T$ mutant cells were irradiated with 1 Gy of X-rays, and these cells were transferred to T25 flasks with the same number of non-irradiated HPRT normal cells. We regarded this co-culture equivalent to the bystander condition. In contrast to the bystander condition, non-irradiated mutant and normal HPRT cells were co-cultured in the same T25 (control), and irradiated mutant and normal HPRT cells were co-cultured in the same T25 (irradiated condition). For these three conditions, cells were cultured for 7 days with the transfer of cells into a new T25 every 2 or 3 days. 100 cells from the co-cultured population in T25 were transferred into a 100 mm petri dish with hypoxanthine-aminopterine-thymidine (HAT, Sigma-Aldrich, Tokyo, Japan) medium and incubated for 7-10 days to make some colonies HAT resistant. HAT resistant cells are HPRT normal cells, because HPRT mutant cells cannot survive in the HAT medium. Colonies were selected at random for further analysis for the progenies of non-irradiated cells, bystander cells and irradiated cells. Cells chosen were expanded to $2-5 \times 10^{6}$ and the micronucleus assay performed as described above. 
Statistical analysis was performed using Student's $t$ test and one-way analysis of variance (ANOVA).

\section{Results}

The results of micronuclei induction immediately after irradiation are shown in Figure

1. In all dose points examined, the yields of micronuclei in xrs5 cells were significantly higher than in the control CHO cells ( $p<0.001$ by student $t$ test), and those in EM9 cells were slightly higher. These results are consistent with differences in clonogenic survival (data not shown), and show that micronuclei formed immediately after irradiation are mainly caused by abnormal functions in the repair of DNA double strand breaks. The results of delayed micronuclei formations are shown in Figure 2. Dose dependent increases were observed in CHO and EM9 cells up to $1 \mathrm{~Gy}$, additionally, significantly higher levels of micronuclei were observed in both CHO and EM9 after 0.5 or 1 Gy irradiation compared to non-irradiated cells. Interestingly, no delayed inductions of micronuclei, above control levels, were observed in xrs 5 cells at these doses. The percentage of binucleated cells with micronuclei in xrs5 cells one week after irradiation of 0 to 1 Gy were from 9.6 to $9.9 \%$. As we could not exclude the possibility that cytogenetic damage by direct irradiation are included in the results in Figure 2, delayed effects in the irradiated population were examined in clones of irradiated cells as described in Figure 3. 
In order to clarify the contribution of a bystander effect in the delayed response, cells receiving bystander signals from irradiated cells via co-culture were also examined, using an HPRT mutation selection process (Figure 3). Six to nine clonal populations for each cell line (non-irradiated, bystander, irradiated) were analyzed. As shown in Figure 4, some progenies of irradiated CHO and EM9 showed higher levels of micronuclei, but not xrs5. Average percentage of binucleated cells with micronuclei are shown as bars in Figure 4, and significant differences were observed between the non-irradiated and irradiated condition in $\mathrm{CHO}(p<0.05)$. Although increased levels of bystander induced micronuclei were not observed in CHO or EM9, xrs5 showed significantly higher levels.

\section{Discussion}

In the present study, we confirmed the induction of delayed genetic effects especially at low X-ray doses. As shown in our previous report (Somodi et al. 2005), cells that are defective in single strand breaks repair are susceptible to radiation induced delayed effects at high doses. Our present study also shows higher delayed induction of micronuclei in EM9, suggesting that unrepaired or misrepaired DNA damageare important for the expression of delayed genetic effects at low X-ray doses. In directly irradiated Ku80 deficient xrs5 cells, no delayed induction of micronuclei is observed at 7 days post-irradiation and about 3 weeks in the 
case of clonal analysis, implicating a Ku80 dependent process in the induction of delayed effect.

Although we could not exclude the possibility that delayed effects are induced much later time in xrs5, this result is supported by previous reports (Chang and Little 1992; Suzuki et al. 2010) which suggest that non-homologous end joining (NHEJ) occurs immediately after irradiation, leading to mis-rejoining sites, which are the main trigger of genomic instability. However, higher levels of micronuclei in progenies of bystander cells were detected in our experiment using Ku80 deficient xrs5 (Figure 4). Therefore, not only NHEJ but also another process, that is characteristically induced by bystander effect in DSB repair deficient cells, is involved in delayed effects. In the report by Watson et al. (2000), the contribution of bystander effects to genomic instability was suggested by the analysis of chromosome aberration in mouse bone marrow cells. Our data strongly support this idea.

We need to clarify why only bystander but, not directly irradiated cells, showed delayed effects in the xrs5 line (Figure 4). We have previously reported higher induction of micronuclei via a bystander effect in xrs5 compared to CHO and EM9 (Kashino et al. 2004; Kashino et al. 2007). However, increased levels of micronuclei induced by the bystander effect in previous reports are much less than those in directly irradiated cells. Therefore, bystander induced DSBs are unlikely to be a trigger of delayed micronuclei induction in xrs5 in the present study. Also, we have hypothesised that mitochondrial modulation is involved in 
genomic instability by bystander effect. Our recent results suggest that mitochondrial membrane potentials were similarly reduced both in directly irradiated and bystander cells in the range from 0.2 to $4 \mathrm{~Gy}$ (data not shown). This epigenetic mitochondrial modulation seems to lead to the production of ROS (Kobashigawa et al. 2011), which is a key factor in genomic instability (Clutton et al. 1996, Roy et al. 2000, Limoli et al. 2003, Rugo et al. 2004, Tominaga et al. 2004, Slane et al. 2006). Due to the higher sensitivity of xrs5, unrepaired irradiated cells, in which mitochondrial modulation has occurred, should be removed from the population during clonal expansion. In xrs5 bystander cells, lethal effects are increased, but the level for mitochondrial modulation is sufficiently reduced. Therefore, it is possible that for xrs 5 bystander cells, cell survival and genomic instability is maintained through reactive oxygen species (ROS) production by mitochondrial modulation. In bystander conditions, $\mathrm{CHO}$ and EM9 clones did not show higher levels of micronuclei, therefore, a Ku80 deficient phenotype is involved in genomic instability through a bystander dependent mechanism. We aim to clarify the epigenetic phenotype leading to genomic instability in future studies.

In conclusion, this study highlights that DSB repair deficiency leads to the accumulations of unstable progeny cells thorough bystander effects, while the DSB repair process contributes to genomic instability via micronucleus induction in the progeny of directly irradiated cells. 


\section{Acknowledgements}

The authors are grateful for support from Cancer Research UK [CUK] grant number

C1513/A7047, the Gray Cancer Institute and the European NOTE (Non-targeted effects of ionizing radiation) project (FI6R 036465).

\section{Declaration of interest}

The authors report no conflicts of interest. The authors alone are responsible for the content and writing of the paper. 


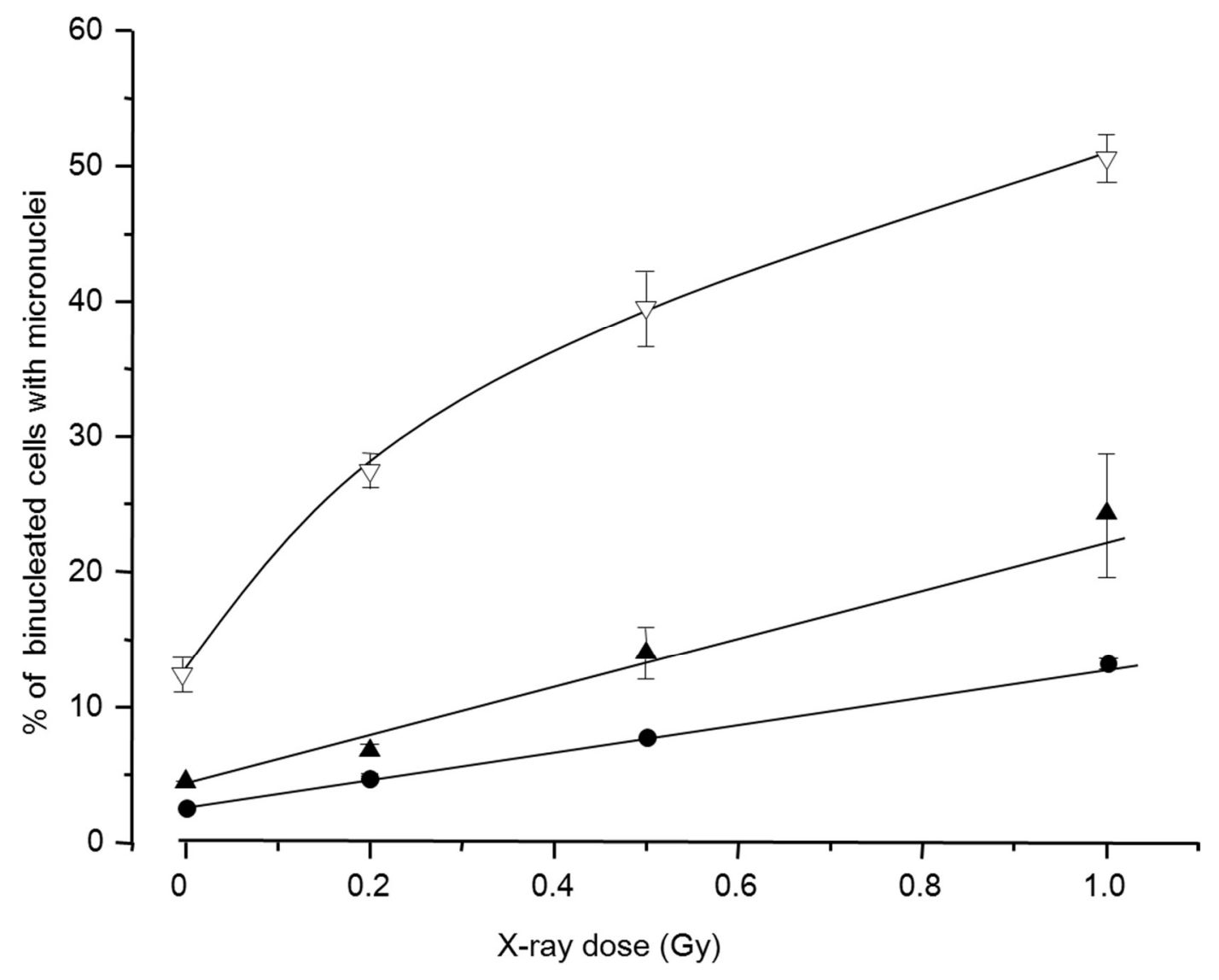

Figure 1 Micronuclei induction immediately after X-irradiation in repair deficient $\mathrm{CHO}$ cell lines (the acute effect). The average yields of binucleated cells with micronuclei $+/$ - standard error of mean (SEM) from three individual experiments are shown for control $\mathrm{CHO}$ (closed circle), repair deficient EM-9 (closed triangle) and xrs5 (open triangle). 


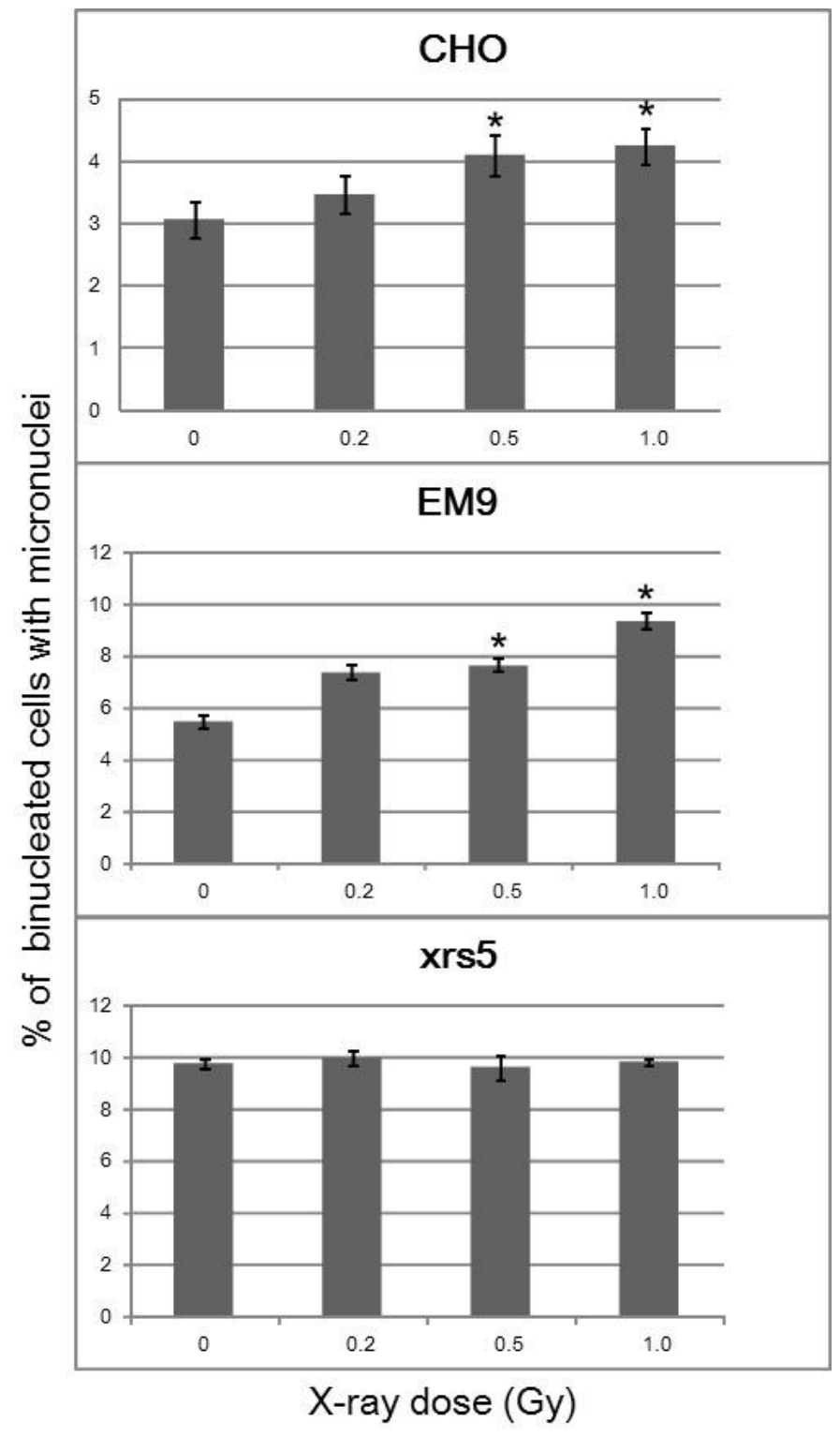

Figure 2 Micronuclei induction one week after X-irradiation in repair deficient $\mathrm{CHO}$ cell lines (delayed effect). The average yields of binucleated cells with micronuclei $+/$ - standard error of the mean (SEM) from three individual experiments are shown for control $\mathrm{CHO}$ (upper panel), repair deficient EM9 (middle panel) and xrs5 (lower panel) cells. Significant differences were observed between non-irradiated cells and irradiated cells ( ${ }^{*} p<0.05$ by student $t$ test). 


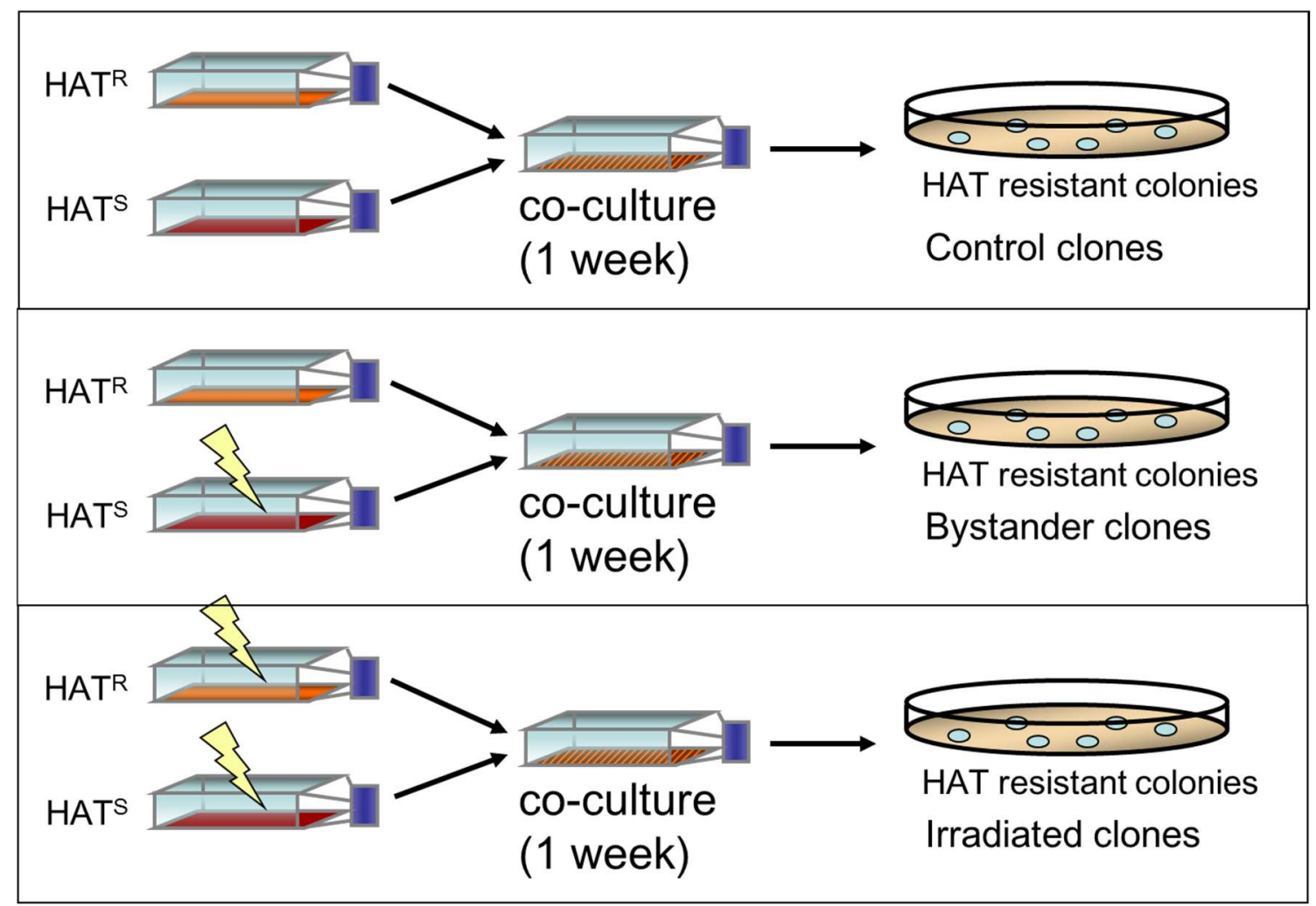

Figure 3 A schema of clone analysis in non-irradiated, bystander and irradiated conditions.

HAT $^{\mathrm{R}}$ and HAT ${ }^{\mathrm{S}}$ means HAT resistant (HPRT normal cells) and HAT sensitive (HPRT mutant

cells), respectively. In the non-irradiated condition (upper), bystander condition (middle) and

irradiated condition (lower), HAT resistant clones were obtained after HAT selection, and were analyzed . 

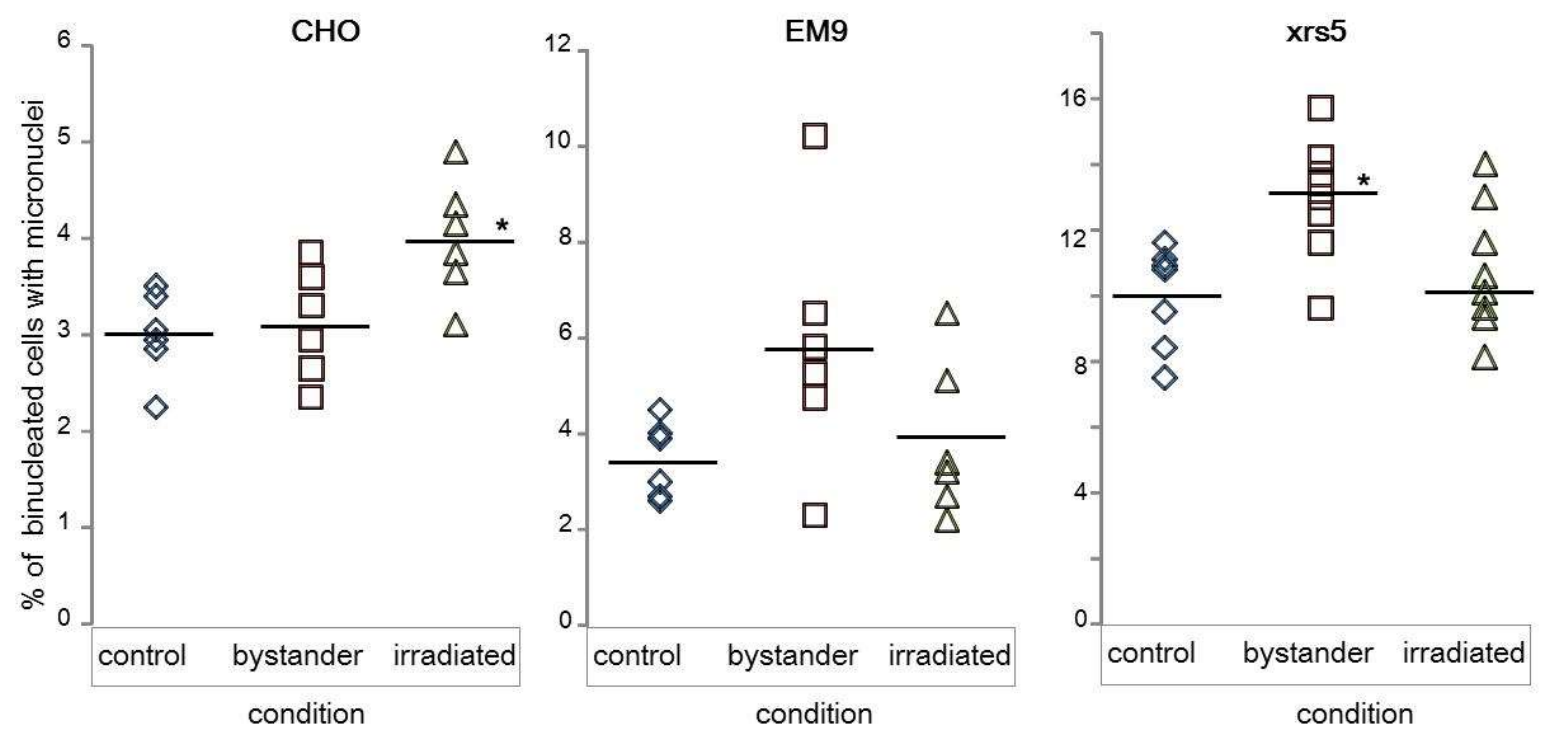

Figure 4 Percentage of micronuclei in clonal analysis. The levels of micronuclei in each

clone were analyzed in the control non-irradiated condition (left), bystander condition (middle)

and irradiated condition (right). Each plot represents the result in each clonal population obtained from each condition as described in Materials and Methods. Bars in the figure show the average for each condition. Significant differences were observed between the distribution of control and bystander or irradiated condition $(* p<0.05$ by one-way ANOVA). 


\section{References}

Caldecott KW, Mckeown CK, Tucker JD, Ljungquist S, Thompson LH. 1994. An interaction between the mammalian DNA repair protein XRCC1 and DNA ligase III. Molecular and Cellular Biology 14: 68-76.

Chai Y, Hei TK. 2008. Radiation Induced Bystander Effect in vivo. Acta Medica Nagasaki 53: S65-S69.

Chang WP, Little JB. 1992. Evidence that DNA double-strand breaks initiate the phenotype of delayed reproductive death in Chinese hamster ovary cells. Radiation Research 131: 53-59.

Clutton SM, Townsend KM, Walker C, Ansell JD, Wright EG. 1996. Radiation-induced genomic instability and persisting oxidative stress in primary bone marrow cultures.

Carcinogenesis 17: 1633-1639.

Fench M, Chang WP, Kirsch-Volders M, Holland N, Bonassi S, Zeiger E. 2003. HUMN project: detailed description of the scoring criteria for the cytokinesis-block micronucleus assay using isolated human lymphocyte cultures. Mutation Research 534: 65-75.

Goodarzi AA, Jeggo P, Lobrich M. 2010. The influence of heterochromatin on DNA double strand break repair: Getting the strong, silent type to relax. DNA Repair 9: 1273-1282. Hamada N, Maeda M, Otsuka K, Tomita M. 2011. Signaling pathways underpinning the 
manifestations of ionizing radiation-induced bystander effects. Current Molecular

Pharmacology 4: 79-95.

Ilnytskyy Y, Kovalchuk O. 2011. Non-targeted radiation effects-an epigenetic connection.

Mutation Research 714: 113-125.

Kadhim MA, Macdonald DA, Goodhead DT, Lorimore SA, Marsden SJ, Wright EG. 1992.

Transmission of chromosomal instability after plutonium alpha-particle irradiation. Nature 355:

738-740.

Kashino G, Prise KM, Schettino G, Folkard M, Vojnovic B, Michael BD, Suzuki K, Kodama S,

Watanabe M. 2004. Evidence for induction of DNA double strand breaks in the bystander

response to targeted soft X-rays in CHO cells. Mutation Research $556: 209-215$.

Kashino G, Suzuki K, Matsuda N, Kodama S, Ono K, Watanabe M, Prise KM. 2007. Radiation induced bystander signals are independent of DNA damage and DNA repair capacity of the irradiated cells. Mutation Research $619: 134-138$.

Kashino G, Liu Y, Suzuki M, Masunaga S, Kinashi Y, Ono K, Tano K, Watanabe M. 2010. An alternative mechanism for radioprotection by dimethyl sulfoxide; possible facilitation of DNA double-strand break repair. Journal of Radiation Research 51: 733-740,

Koturbash I, Rugo RE, Hendricks CA, Loree J, Thibault B, Kutanzi K, Pogribny I, Yanch JC, Engelward BP, Kovalchuk O. 2006. Irradiation induces DNA damage and modulates epigenetic 
effectors in distant bystander tissue in vivo. Oncogene 25: 4267-4275.

Kobashigawa S, Suzuki K, Yamashita S. 2011. Ionizing radiation accelerates Drp1-dependent mitochondrial fission, which involves delayed mitochondrial reactive oxygen species production in normal human fibroblast-like cells. Biochemical Biophysics Research Communication 414: 795-800.

Limoli CL, Giedzinski F, Morgan WF, Swarts SG, Johns GD, Hyun W. 2003. Persistent oxidative stress in chromosomally unstable cells. Cancer Research 63: 3107-3111.

Little JB, Nagasawa H, Pfenning T. Vetrovs H. 1997. Radiation-induced genomic instability: delayed mutagenic and cytogenetic effects of X rays and alpha particles. Radiation Research 148: 299-307.

Mahaney BL, Meek K, Lees-Miller SP. 2009. Repair of ionizing radiation-induced DNA double-strand breaks by non-homologous end-joining. Biochemical Journal 417: 639-650.

Morgan WF. 2003a. Non-targeted and delayed effects of exposure to ionizing radiation: I. Radiation-induced genomic instability and bystander effects in vitro. Radiation Research 159: $567-580$.

Morgan WF. 2003b. Non-targeted and delayed effects of exposure to ionizing radiation: II. Radiation-induced genomic instability and bystander effects in vivo, clastogenic factors and transgenerational effects. Radiation Research 159: 581-596. 
Nussenzweig A, Sokol K, Burgman P, Li L, Li GC. 1997. Hypersensitivity of Ku80-deficient cell lines and mice to DNA damage: the effects of ionizing radiation on growth, survival, and development. Proceeding of the National Academy of Sciences, USA 94: 13588-13593.

Prise KM, O'Sullivan JM. Radiation-induced bystander signalling in cancer therapy. Nature Review Cancer 9: 351-360.

Roy K, Kodama S, Suzuki K, Fukase K, Watanabe M. 2000. Hypoxia relieves X-ray-induced delayed effects in normal human embryo cells. Radiation Research 154: 659-666.

Rugo RE, Schiestl RH. 2004. Increases in oxidative stress in the progeny of x-irradiated cells.

Radiation Research 162: 416-425.

Sawant SG, Randers-Pehrson G, Geard CR, Brenner DJ, Hall EJ. 2001. The bystander effect in radiation oncogenesis: I. Transformation in $\mathrm{C} 3 \mathrm{H} 10 \mathrm{~T} 1 / 2$ cells in vitro can be initiated in the unirradiated neighbors of irradiated cells. Radiation Researh 55: 397-401.

Slane BG, Aykin-Burns N, Smith BJ, Kalen AL, Goswami PC, Domann FE, Spitz DR. 2006. Mutation of succinate dehydrogenase subunit $\mathrm{C}$ results in increased $\mathrm{O}_{2}{ }^{-}$, oxidative stress, and genomic instability. Cancer Research 66: 7615-7620.

Seoane A, Guerci A, Dulout F. 2007. Genetic instability induced by low doses of x-rays in hamster cells. International Journal of Radiation Biology 83: 81-87.

Shen MR, Zdzienicka MZ, Mohrenweiser H, Thompson LH, Thelen MP. 1998. Mutations in 
hamster single-strand break repair gene XRCC1 causing defective DNA repair. Nucleic Acids Research 26: 1032-1037.

Somodi Z, Zyuzikov NA, Kashino G, Trott KR, Prise KM. 2005. Radiation-induced genomic instability in repair deficient mutants of Chinese hamster cells. International Journal of Radiation Biology 81: 929-936.

Sterpone S, Cozzi R. 2010. Influence of XRCC1 Genetic Polymorphisms on Ionizing Radiation-Induced DNA Damage and Repair. Journal of Nucleic Acids, Article ID 780369. Suzuki K, Ojima M, Kodama S, Watanabe M. 2003. Radiation-induced DNA damage and delayed induced genomic instability. Oncogene 22: 6988-6993.

Suzuki K, Kashino G, Kodama S, Watanabe M. 2009. Long-term persistence of X-ray-induced genomic instability in quiescent normal human diploid cells. Mutation Research 671: 33-39. Suzuki K, Kodama S, Watanabe M. 2010. Role of Ku80-dependent end-joining in delayed genomic instability in mammalian cells surviving ionizing radiation. Mutation Research 683: 29-34.

Thacker J, Zdzienicka MZ. 2003. The mammalian XRCC genes: their roles in DNA repair and genetic stability. DNA Repair 2: 655-672.

Tominaga H, Kodama S, Matsuda N, Suzuki K, Watanabe M. 2004. Involvement of reactive oxygen species (ROS) in the induction of genetic instability by radiation. Journal of Radiation 
Research 45: 181-188.

Toyokuni H, Maruo A, Suzuki K, Watanabe M. 2009. The contribution of radiation-induced large deletion of the genome to chromosomal instability. Radiation Research 17: 198-203.

Watson GE, Lorimore SA, Macdonald DA, Wright EG. 2000. Chromosomal instability in unirradiated cells induced in vivo by a bystander effect of ionizing radiation. Cancer Research 60: $5608-5611$. 